\title{
ANALYSIS OF BASE AND COMPETITIVE COMMODITIES OF CROP SUBSECTOR AND ITS EFFECT ON GDRP GROWTH OF LANGKAT REGENCY
}

\author{
Khalish Khairina ${ }^{1 *}$, Fitrawaty $^{2}$ \\ $1^{1 *}$ Postgraduate Program, Universitas Negeri Medan \\ ${ }^{2}$ Faculty of Economics, Universitas Negeri Medan \\ Email: khairina@gmail.com
}

\begin{abstract}
Economic Growth is one of indicator which commonly used to observe economic development in a region. Conceptually, economic growth of a region is determined by sector values in producing goods and services. GDRP of Langkat regency is mostly dominated by agriculture, forestry and fisheries sector. Food security that Langkat Regency plan to be achieved really depends on food crops' supply. However crops' contribution is decreased every year. Therefore, it's needed to examine which leading and highly competitive crops' commodities. This study aimed to determine and analyze a base and competitive crops' subsector and its effect on GDRP Langkat Regency. LQ was used to determine the base and non base commodities. While the analysis of RCA and $\mathrm{MCl}$ were used to see the commodities competitiveness. and to analyse its effect by using Ordinary Least Square. The type of data used was time series since 1996 to 2015 by using Eviews 7.0. Data was obtained from BPS Langkat Regency and Agriculture Department of Langkat Regency. The result of this study showed that paddy, corn, soybean and mungbean were base commodities of crops with average $L Q>1$. This study also showed that paddy, corn, soybean and mungbean were highly competitive commodities with average $R C A>1$. Average $\mathrm{MCl}$ each commodities is $>0,75$ showed that commodities trade's less spread (concentrated). Regression result showed that paddy has positive effect on GDRP growth in supply side (prob RCA 0,0035 <0,05). Corn also showed that has positive effect on GDRP growth in supply and demand side (prob RCA 0,0016 < 0,05 and $\mathrm{MCl} 0,0193<0,05)$. Soybean showed that has positive effect on GDRP growth in production supply $(L Q 0,0032<0,05)$ and Mungbean also showed that has positive effect on GDRP growth in production supply $(L Q 0,0001<0,05)$.
\end{abstract}

Key words: Base Commodities, Competitiveness, GDRP Growth, $L Q, R C A, M C l$, and OLS (Ordinary Least Square)

\section{INTRODUCTION}

\footnotetext{
7 conomic growth is one of the economic indicators that is usually used to observe changes in the economic conditions of a region. Economic growth is a change in an economic condition continuously towards a better condition. Economic growth is a quantitative economic indicator, changes in economic conditions are measured by numbers.
} 
Many factors affect the level of economic growth in a region, both from the leading sectors and from other contributions. The implementation of the regional autonomy policy aims to accelerate the regional development process. Regions are given the discretion in regulating and managing their governmental affairs to accelerate the realization of public welfare through increasing regional competitiveness by taking into account the principles of democracy, equity, justice and the specificity of a region. The granting of authority to these regions should give regions more opportunities to implement policies for economic development. Economic development is an attempt to expand employment, equitable income distribution and a shift in the economic structure from the primary sector to the tertiary sector. Economic growth which is increasing from period to period is the goal of policy by exploiting the existing potential and resources.

North Sumatera Province is a province consisting of 33 regencies / cities. Districts and cities that exist each have a variety of geographic conditions that are different from the others. This difference between one region and another causes a large number of natural resources that can be explored and intensified. One of them is Langkat district. Langkat is known as one of the large districts that has a lot of potential, including potential in the agricultural sector. As is well known, the agricultural sector is able to absorb a lot of labor. However, the GRDP growth of Langkat Regency is still considered too low compared to the average GRDP growth of North Sumatera province. This can be seen in the following table:

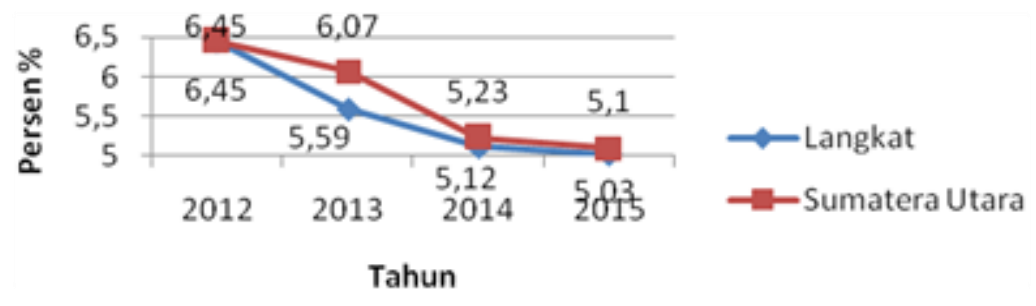

Figure 1: Comparison of GRDP Growth Rates in Langkat and North Sumatera Regencies at Constant Prices 2012-2015 (in Percent)

Seeing this figure, it can be said that GRDP growth of Langkat Regency is still low compared to the average GRDP growth of North Sumatera province. From the table above we can see that from 2012 to 2015 the GRDP growth of Langkat Regency was always below the average GRDP growth of North Sumatera. From the table above we can see that there is a downward trend in economic growth in Langkat Regency. In 2012 the GRDP growth in Langkat and North Sumatera was at 6.45\%. In 2013, the GRDP growth of North Sumatera and Langkat also decreased, but the growth of Langkat Regency was still below the average, namely $5.59 \%$. The district economy continued to slow down in 2014 by $5.12 \%$ while for 2015 it was $5.03 \%$. 
Table 1: Percentage Distribution of Agriculture, Forestry and Fisheries Sector

\begin{tabular}{|c|c|c|c|c|c|c|}
\hline \multirow[t]{2}{*}{ No } & \multirow[t]{2}{*}{ Business field } & \multicolumn{5}{|c|}{$\begin{array}{l}\text { Percentage of Distribution in Agriculture, Forestry } \\
\text { and Fisheries Sector (\%) }\end{array}$} \\
\hline & & 2011 & 2012 & 2013 & 2014 & 2015 \\
\hline \multicolumn{2}{|c|}{ A. Agriculture, Forestry and Fisheries } & 44.83 & 44.22 & 43.75 & 41.95 & 40.46 \\
\hline \multirow[t]{8}{*}{1} & $\begin{array}{l}\text { Agriculture, Animal Husbandry, } \\
\text { Hunting and Agricultural Services }\end{array}$ & 41.14 & 40.58 & 39.96 & 38.03 & 36.45 \\
\hline & a. Crops & 6.94 & 7.11 & 7.02 & 6.63 & 6.56 \\
\hline & b. Seasonal Horticultural Plants & 0.18 & 0.18 & 0.18 & 0.17 & 0.15 \\
\hline & c. Seasonal Plantation & 0.35 & 0.38 & 0.37 & 0.36 & 0.37 \\
\hline & $\begin{array}{l}\text { d. Annual Horticultural Plants and } \\
\text { Others }\end{array}$ & 1.63 & 1.57 & 1.54 & 1.44 & 1.40 \\
\hline & e. Annual Plantation & 24.92 & 24.07 & 23.61 & 22.04 & 20.33 \\
\hline & f. Ranch & 6.74 & 6.89 & 6.86 & 7.03 & 7.25 \\
\hline & g. Agriculture and Hunting Services & 0.38 & 0.37 & 0.37 & 0.38 & 0.38 \\
\hline 2 & Forestry and Logging & 0.9 & 0.88 & 0.85 & 0.85 & 0.84 \\
\hline 3 & Fishery & 2.79 & 2.77 & 2.93 & 3.08 & 3.17 \\
\hline
\end{tabular}

Source: Statistics Indonesia of Langkat Regency

Based on the table above, the agriculture, forestry and fisheries sectors provide a distribution of up to $40 \%$. In 2011 the agricultural, forestry and fisheries sectors provided a distribution of $44.83 \%$, then the distribution decreased in 2012 , namely $44.22 \%$. In the following year, namely in 2013 the distribution became 43.75\%. In 2014, the distribution of the agriculture, forestry and fisheries sectors became $41.95 \%$ and decreased in 2015 to $40.46 \%$.

Of all the sub-sectors of agriculture, forestry and fisheries, the annual plantation subsector provides the largest distribution. In 2011 the annual estate subsector gave a distribution of $24.92 \%$. In 2012, the sub-sector distribution experienced a decline, namely 24.07 and in 2013 the distribution decreased to $23.61 \%$. In the following year, namely in 2014, the distribution became $22.04 \%$ and became $20.33 \%$ in 2015 .

The description above illustrates that the sub-sectors of agriculture, forestry and fisheries. some have increased and also decreased. In the 2014-2019 Langkat Regency mid-term regional development plan, food security is an ideal that will be realized by Langkat Regency by protecting the transfer of planted land. This is done in an effort to build food security and sovereignty. When talking about food security, we need to pay attention to the development of the food crop sub-sector, which is the main source for realizing these goals. However, the food crop sub-sector is one of the sub-sectors that is experiencing a decline every year. In fact, its position as the second largest contributor to distribution declined to become the third position replaced by the livestock subsector in 2014 and 2015. The food crop subsector consists of rice, corn, cassava, sweet potatoes, peanuts, soybeans and green beans. The following is a table of income from commodities in the food crop subsector: 
Table 2: Income of Several Food Crop Commodities in Langkat Regency, 2011 - 2015

\begin{tabular}{|c|c|c|c|c|c|}
\hline \multirow{2}{*}{ Commodity } & \multicolumn{5}{|c|}{ Year } \\
\hline & 2011 & 2012 & 2013 & 2014 & 2015 \\
\hline Rice & $\begin{array}{l}1,110,164,730 \\
, 560\end{array}$ & $\begin{array}{l}1,160,386,165 \\
073\end{array}$ & $\begin{array}{l}1,175,713,991, \\
898\end{array}$ & $\begin{array}{l}\text { 1,197,661,590, } \\
036\end{array}$ & $\begin{array}{l}1,249,399,806, \\
366\end{array}$ \\
\hline Corn & $\begin{array}{l}240,132,878,3 \\
34\end{array}$ & $\begin{array}{l}257,662,527,00 \\
9\end{array}$ & $\begin{array}{l}289,555,876,39 \\
6\end{array}$ & $\begin{array}{l}223,982,314,81 \\
4\end{array}$ & $\begin{array}{l}233,972,802,19 \\
0\end{array}$ \\
\hline Cassava & $\begin{array}{l}12,283,221,04 \\
3\end{array}$ & $14,877,353,735$ & $14,674,938,482$ & $8,613,748,060$ & $13,559,970,321$ \\
\hline $\begin{array}{l}\text { Sweet } \\
\text { potato }\end{array}$ & $1,278,454,474$ & $2,549,313,611$ & $1,103,019,064$ & $1,145,994,376$ & $2,748,917,087$ \\
\hline Peanuts & $1,203,536,758$ & $1,423,913,147$ & $1,179,094,626$ & $71,960,576$ & $2,490,728,150$ \\
\hline Soybeans & $3,742,110,771$ & $3,845,167,033$ & $2,968,823,712$ & $2,708,051,296$ & $5,410,634,045$ \\
\hline $\begin{array}{l}\text { Green } \\
\text { beans }\end{array}$ & $3,440,811,928$ & $4,795,406,323$ & 1,449,716,979 & $1,543,179,501$ & $3,133,114,654$ \\
\hline Total & $\begin{array}{l}1,372,245,743 \\
, 868\end{array}$ & $\begin{array}{l}\text { 1,445,539,845, } \\
931\end{array}$ & $\begin{array}{l}1,486,645,461, \\
157\end{array}$ & $\begin{array}{l}1,435,726,838, \\
659\end{array}$ & $\begin{array}{l}1,510,715,972, \\
813\end{array}$ \\
\hline
\end{tabular}

Source: Langkat Regency Agriculture Office

The table above shows the development of income from the food crop subsector. So it can be seen that the largest income is given by the rice commodity. In 2011, income from rice reached IDR 1,110,164,730,560. In 2012 rice income increased to Rp $1,160,386,165,000$, while in 2013 the income contributed by rice commodities was Rp $1,175,713,991,900$. In 2014, the income contributed by rice commodities declined again to $\mathrm{Rp} 1,197,661,590,000$. Then in 2015 the income from rice commodities increased again to $\mathrm{Rp} 1,249,399,806,000$. As is well known, the agricultural sector plays an important role in economic development as a prerequisite for achieving better economic development. In a study conducted by Enu (2014), it is stated that the agricultural sector is the key to economic growth and the development process of Ghana. This sector not only influences but also absorbs labor and provides raw materials for industrial growth and development.

The contribution of the agricultural sector plays an important role in the transitional period reaching the take-off stage. Agricultural progress is needed to ensure the supply of foodstuffs for the increasing population and so that the urban population which is increasing rapidly as a result of industrialization can obtain sufficient foodstuffs. Traditionally, the role of agriculture in economic development has been seen only as a passive and only as a supporting element. If a region wants smooth and sustainable development, then the region must start from the rural areas in general and the agricultural sector in particular (Todaro and Smith in Agustono, 2013). The ability of the agricultural sector to provide sufficient foodstuffs not only avoids the danger of hunger, but can also direct local income to import other goods that are more useful for development. Furthermore, developments in the agricultural sector can also support developments in the industrial sector. Increased productivity in the agricultural sector will expand the market for various industrial activities. The increase in farmers' income will expand the industrial consumer goods market, and the increase in agricultural productivity will expand the market for modern agricultural-producing industries. So, by

QE Journal | Vol.09 - No.02 - 38 
knowing what are the leading commodities in the food crop sub-sector in Langkat, it is hoped that it can be developed better. From time to time, the economic situation and conditions never stand still. Always raises a number of observable phenomena. Macroeconomic conditions describe the state of economic changes that affect many households, markets and firms. These changes can be observed by several variables, namely GRDP, economic growth and inflation.

\section{RESEARCH METHOD}

This type of research is descriptive research and causal research. Descriptive research is a form of research aimed at describing existing phenomena, both natural phenomena and man-made phenomena. Causal research can be used to prove empirically the effect of food crop commodities on GRDP growth in Langkat district. The method used in collecting data is through documentation study, namely by using and studying data through tracing of various existing documents and other documents related to this research. In this study, the data collected were GRDP and yields of rice, maize, cassava, sweet potatoes, peanuts, soybeans, and green beans in addition to other relevant data. The type of data used in this study is secondary data which is data obtained from the local government of Langkat Regency, this data is sourced from Statistics Indonesia of North Sumatera Province and BPS Langkat Regency. The data used in this research is GRDP and commodity production value from the food crop sub-sector of Langkat Regency. Secondary data used in this research is time series data (periodic data) based on constant prices in 2010, 2000, and 1993 during the last 20 years, 1996 to 2015.

\section{RESULT AND DISCUSSION}

\section{General Description of the Research}

Table 3: Gross Regional Domestic Product of Langkat Regency at Constant Prices by Industry, 2011 - 2015 (Million Rupiah)

\begin{tabular}{|c|c|c|c|c|c|c|}
\hline NO & KATEGORI & 2011 & 2012 & 2013 & 2014* & $2015^{* *}$ \\
\hline 1 & $\overline{\text { Forestry Agriculture and Fisheries }}$ & $8,886,961.40$ & $9,368,942.80$ & $9,810,501.10$ & $10,149,337.10$ & $10,623,557.90$ \\
\hline 2 & Mining and excavation & $1,863,502.70$ & $2,002,365.50$ & $2,116,374.20$ & $2,228,313,30$ & $2,335,253,30$ \\
\hline 3 & Processing industry & $2,924,233.70$ & $3,098,582.80$ & $3,255,652.70$ & $3,408,877,30$ & $3,577,007,30$ \\
\hline 4 & Procurement of Electricity and Gas & $56,811.10$ & $51,525,30$ & $51,831.80$ & $52,215.90$ & $54,396.70$ \\
\hline 5 & $\begin{array}{l}\text { Waste Management and Recycling } \\
\text { Water Supply }\end{array}$ & $7,951.40$ & $8,384.50$ & $8,651.80$ & $9,001.50$ & $9,341.50$ \\
\hline 6 & Construction & $1,217,647.80$ & $1,327,748.90$ & $1,454,514.50$ & $1,638,614.50$ & $1,747,714.50$ \\
\hline 7 & $\begin{array}{l}\text { Wholesale and Retail Trade; Car and } \\
\text { Motorcycle Repair }\end{array}$ & $1,850,951.60$ & $1,960,335.70$ & $2,065,328.40$ & $2,170,827,30$ & $2,263,121.00$ \\
\hline 8 & Transportation and Warehousing & $371,766.40$ & $396,216.00$ & $426,587.50$ & $457,359.50$ & $488,574.50$ \\
\hline 9 & $\begin{array}{l}\text { Provision of Accommodation and } \\
\text { Food and Drink }\end{array}$ & $354,934.80$ & $390,099.90$ & $419,794.20$ & $446,871.40$ & $473,949.40$ \\
\hline 10 & Information and Communication & $204,892.40$ & $225,235.00$ & $245,942.90$ & $266,191.40$ & $289,191.40$ \\
\hline 11 & Financial Services and Insurance & $314,838.30$ & $363,855.10$ & $397,007.70$ & $435,890.10$ & $464,772.10$ \\
\hline 12 & Real Estate & $492,495.00$ & $539,955.50$ & $583,861.60$ & $628,182.50$ & $657,503.50$ \\
\hline 13 & Company Services & $91,125.70$ & $99,430.70$ & $108,052.70$ & $115,359.80$ & $122,666.80$ \\
\hline 14 & $\begin{array}{l}\text { Compulsory Government } \\
\text { Administration of Defense and Social } \\
\text { Security }\end{array}$ & $608,567,30$ & $659,554.60$ & $689,466.60$ & $729,942.90$ & $770,418.90$ \\
\hline 15 & Education Services & $226,077.80$ & $236,558.10$ & $255,565.70$ & $270,826.00$ & $286,088.00$ \\
\hline 16 & Health Services and Social Activities & $90,711.30$ & $96,554.90$ & $103,928.10$ & $109,122.60$ & $114,316.60$ \\
\hline 17 & Other Services & $31,266.40$ & $33,334.60$ & $36,417,30$ & $40,075.10$ & $43,733.10$ \\
\hline \multicolumn{2}{|r|}{ Produk Domestik Regional Bruto } & $19,594,735.10$ & $20,858,679.90$ & $22,029,478.80$ & $23,157,008.20$ & $24,321,606.50$ \\
\hline
\end{tabular}

Source: Statistics Indonesia of Langkat Regency 
By looking at the table above, we can see that the GRDP of Langkat Regency at constant prices has always increased from 2011 to 2015. In 2011, the district's GRDP was IDR $19,594,735.10$ and then in 2012 it was IDR 20,858,679.90. Likewise in the following year and in 2015 the GRDP of Langkat Regency was IDR 24,321,606.50

However, the economy of Langkat Regency is experiencing a slowdown if you look at the growth rate of Langkat Regency's GRDP. The GRDP growth of Langkat Regency in 2015 reached 5.03 percent, while in 2014 it was 5.12 percent. This is due to the fact that the majority of business fields have experienced a growth slowdown, namely the Agriculture, Forestry and Hunting business fields, Mining and Excavation business fields, Processing Industry business fields, Electricity and Gas Supply business fields, and Large and Retail Trade Business Fields, Transportation and Warehousing, the field of providing accommodation and food and beverage, real estate business, corporate services business field, educational service business field and health and social activity service business.

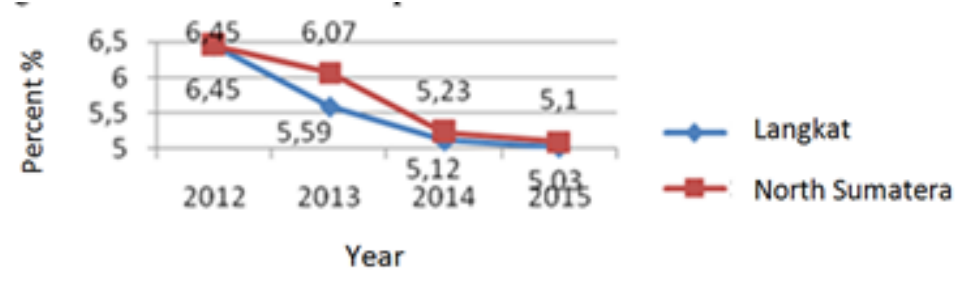

Figure 2: Comparison of GRDP Growth Rates in Langkat and North Sumatera Regencies at Constant Prices 2012-2015 (in Percent)

When compared to the economic growth of North Sumatera, the economic growth of Langkat Regency has experienced a growth pattern similar to that of North Sumatera, which has experienced a slowdown in growth from 2011 to 2015. Despite slowing growth, the position of economic growth in Langkat Regency has always been below that of North Sumatera, namely by 5.03 percent, while North Sumatera grew by 5.23 percent in 2015

\section{LQ analysis}

Langkat Regency is one of the regencies in North Sumatera which consists of 23 districts. The sub-districts in Langkat Regency, of course, have different potentials from one another. So to see which potential should be developed, an analytical tool, namely LQ (Location Quotient) can be used.

Table 4: Value of Food Crop Commodities in Langkat Regency 2011 - 2015 (Million Rupiah)

\begin{tabular}{|c|c|c|c|c|c|}
\hline \multirow{2}{*}{ Commodity } & \multicolumn{5}{|c|}{ Year } \\
\hline & 2011 & 2012 & 2013 & 2014 & 2015 \\
\hline Rice & $\begin{array}{l}1,110,164,730, \\
560\end{array}$ & $\begin{array}{l}1,160,386,165, \\
073\end{array}$ & $\begin{array}{l}1,175,713,991, \\
898\end{array}$ & $\begin{array}{l}1,197,661,590, \\
036\end{array}$ & $\begin{array}{l}1,249,399,806, \\
366\end{array}$ \\
\hline Corn & $\begin{array}{l}240,132,878,3 \\
34\end{array}$ & $\begin{array}{l}257,662,527,0 \\
09\end{array}$ & $\begin{array}{l}289,555,876,3 \\
96\end{array}$ & $\begin{array}{l}223,982,314,8 \\
14\end{array}$ & $\begin{array}{l}233,972,802,1 \\
90\end{array}$ \\
\hline Cassava & $\begin{array}{l}12,283,221,04 \\
3\end{array}$ & $\begin{array}{l}14,877,353,73 \\
5\end{array}$ & $\begin{array}{l}14,674,938,48 \\
2\end{array}$ & $8,613,748,060$ & $\begin{array}{l}13,559,970,32 \\
1\end{array}$ \\
\hline
\end{tabular}

QE Journal | Vol.09 - No.02 - 40 


\begin{tabular}{|l|l|l|l|l|l|}
$\begin{array}{l}\text { Sweet } \\
\text { potato }\end{array}$ & $1,278,454,474$ & $2,549,313,611$ & $1,103,019,064$ & $1,145,994,376$ & $2,748,917,087$ \\
\hline Peanuts & $1,203,536,758$ & $1,423,913,147$ & $1,179,094,626$ & $71,960,576$ & $2,490,728,150$ \\
\hline Soybeans & $3,742,110,771$ & $3,845,167,033$ & $2,968,823,712$ & $2,708,051,296$ & $5,410,634,045$ \\
\hline $\begin{array}{l}\text { Green } \\
\text { beans }\end{array}$ & $3,440,811,928$ & $4,795,406,323$ & $1,449,716,979$ & $1,543,179,501$ & $3,133,114,654$ \\
\hline Total & $1,372,245,743$, & $1,445,539,845$, & $1,486,645,461$, & $1,435,726,838$, & $1,510,715,972$, \\
\hline
\end{tabular}

Source: Langkat Regency Agriculture Office

Table 5: Value of Food Crop Commodities in North Sumatera Province 2011-2015

\begin{tabular}{|c|c|c|c|c|c|}
\hline \multirow{2}{*}{ Commodity } & \multicolumn{5}{|c|}{ Year } \\
\hline & 2011 & 2012 & 2013 & 2014 & 2015 \\
\hline Rice & $\begin{array}{l}10,308,858,298 \\
, 547\end{array}$ & $\begin{array}{l}10,551,640,329,3 \\
93\end{array}$ & $\begin{array}{l}10,805,350,094,1 \\
40\end{array}$ & $\begin{array}{l}11,204,934,012,8 \\
31\end{array}$ & $\begin{array}{l}13,300,129,845,0 \\
00\end{array}$ \\
\hline Corn & $\begin{array}{l}2,339,151,639 \\
553\end{array}$ & $\begin{array}{l}2,433,970,171,96 \\
2\end{array}$ & $\begin{array}{l}2,137,302,481,11 \\
8\end{array}$ & $\begin{array}{l}2,095,506,008,05 \\
1\end{array}$ & $\begin{array}{l}2,467,193,753,52 \\
1\end{array}$ \\
\hline Cassava & $\begin{array}{l}740,690,254,67 \\
4\end{array}$ & $856,913,613,178$ & $776,882,317,253$ & $84,546,621,509$ & $631,526,011,186$ \\
\hline $\begin{array}{l}\text { Sweet } \\
\text { potato }\end{array}$ & $\begin{array}{l}141,139,859,16 \\
2\end{array}$ & $137,800,874,677$ & $156,166,628,489$ & $108,287,678,119$ & $413,823,881,750$ \\
\hline Peanuts & $38,574,880,281$ & $41,982,739,540$ & $34,890,789,404$ & $33,998,612,272$ & $29,617,078,822$ \\
\hline Soybeans & $50,244,883,213$ & $23,829,601,096$ & $14,199,258,525$ & $25,087,262,276$ & $28,798,681,965$ \\
\hline Green beans & $15,827,565,001$ & $18,588,866,340$ & $11,420,196,900$ & $14,157,148,136$ & $14,902,261,199$ \\
\hline Total & $\begin{array}{l}13,634,487,380 \\
, 432\end{array}$ & $\begin{array}{l}14,064,726,196,1 \\
87\end{array}$ & $\begin{array}{l}13,936,211,765,8 \\
29\end{array}$ & $\begin{array}{l}13,566,517,343,1 \\
94\end{array}$ & $\begin{array}{l}16,885,991,513,4 \\
44\end{array}$ \\
\hline
\end{tabular}

Source: Statistics Indonesia of North Sumatera

By looking at the income of food crop commodities from Langkat district and North Sumatera province, superior commodities will be obtained from the LQ calculation analysis results. The table is a table of the results of the LQ calculation for food crop commodities for Langkat Regency.

Table 6: Results of the Location Quotient Calculation for Langkat Regency

\begin{tabular}{|l|l|l|l|l|l|l|l|}
\hline \multirow{2}{*}{ Year } & \multicolumn{7}{|c|}{ Commodity } \\
\cline { 2 - 8 } & Rice & \multicolumn{1}{|c|}{ Corn } & Cassava & $\begin{array}{c}\text { Sweet } \\
\text { potato }\end{array}$ & Peanuts & Soybeans & $\begin{array}{c}\text { Green } \\
\text { beans }\end{array}$ \\
\hline 2011 & 1.07 & 1.02 & 0.16 & 0.1 & 0.31 & 0.74 & 2.16 \\
\hline 2012 & 1.07 & 1.03 & 0.17 & 0.2 & 0.33 & 1.57 & 2.51 \\
\hline 2013 & 1.02 & 1.27 & 0.18 & 0.1 & - & 1.96 & 1.19 \\
\hline 2014 & 1.01 & 1.01 & 0.96 & 0.1 & 0.02 & 1.02 & 1.03 \\
\hline 2015 & 1.05 & 1.06 & 0.24 & 0.1 & 0.94 & 2.1 & 2.35 \\
\hline Average & 1.04 & 1.08 & 0.34 & 0.10 & 0.40 & 1.48 & 1.85 \\
\hline
\end{tabular}

Source: Processed Secondary Data (LQ Results 1996-2010, Attached) 
The commodities identified as the leading commodities in the food crop sub-sector in Langkat Regency are rice, corn, soybeans and green beans.

In 2011, the LQ calculation results for rice commodity showed $L Q=1.07$, which means that rice is one of the leading commodities in Langkat Regency. In 2012, the LQ calculation results for rice commodity still showed the same figure in the year, namely 1.07. In 2013 the LQ results showed a decline of up to 1.02 for the commodity of rice. This decrease occurred due to a decrease in the amount of rice production and also the area of rice land in Langkat Regency. The decrease in the amount of production and land area was due to the large number of residents who had shifted their rice fields to become plantations. Even though there is a decline, the commodity still has an LQ value of more than one, which means that rice is still one of the leading commodities in the food crop sub-sector in Langkat Regency. In 2014, there was a decrease in the results of the $L Q$ analysis calculation for rice commodity with a value of $L Q=1.01$. Likewise in 2015 the results of the LQ analysis increased to 1.05. This increase occurred due to an increase in rice production in Langkat Regency.

From the description above, the existing superior commodities such as rice, corn, green beans and soybeans will later become a source of income for Langkat Regency. In theory, this superior commodity will be able to meet the demand in Langkat Regency itself. In addition, this superior commodity can also meet the needs outside the Langkat Regency area. The income earned from selling superior commodities outside this area will later become a source of income for Langkat. The income obtained from the sale of this superior commodity can be used for the development of superior commodities and to encourage the increase in the production of non-superior commodities such as peanuts, cassava and sweet potatoes so that they can become superior commodities.

\section{RCA Analysis}

RCA (Revealed Comparative Advantage) analysis is a method used to measure how the competitiveness of a commodity in an area by looking at the number of sales of commodity production from one region to another. RCA is used to see the advantages of a commodity in terms of sales. This method is able to see the superiority of urban commodity exports which are traded outside the region. If the RCA value is less than 1, this indicates that commodity $i$ is not able to compete, whereas if the RCA value is greater than 1 then this indicates that commodity $i$ has high competitiveness. The following is a table of commodity sales from Langkat Regency to other regions.

Table 7: The Value of Food Crop Commodities in Langkat Regency, 2011 - 2015 (Million Rupiah)

\begin{tabular}{|l|l|l|l|l|l|}
\hline \multirow{2}{*}{ Year } & \multicolumn{5}{c|}{ Commodity } \\
\cline { 2 - 6 } & \multicolumn{1}{|c|}{2011} & \multicolumn{1}{c|}{2012} & \multicolumn{1}{c|}{2013} & \multicolumn{1}{c|}{2014} & \multicolumn{1}{c|}{2015} \\
\hline Rice & $164,571,821$ & $179,276,774$ & $106,885,613$ & $61,017,128$ & $297,337,537$ \\
\hline Corn & $127,829,448$ & $132,202,532$ & $52,766,856$ & $55,793,231$ & $324,143,656$ \\
\hline Cassava & $4,152,740$ & $61,779,900$ & $58,543,810$ & $67,380,243$ & $101,280,363$ \\
\hline Sweet potato & $817,723,224$ & $920,707,012$ & $846,522,398$ & $822,933,587$ & $554,557,564$ \\
\hline Peanuts & $5,015,080$ & 0 & $1,738,700$ & $1,241,225$ & 0 \\
\hline
\end{tabular}




\begin{tabular}{|l|l|l|l|l|l|} 
Soybeans & $1,375,730$ & $13,703,283$ & $1,435,281$ & $7,299,811$ & $25,700,323$ \\
\hline Green beans & 619,057 & $1,133,539$ & 868,962 & 944,415 & $1,352,957$ \\
\hline Total & $1,121,287,100$ & $1,308,803,040$ & $1,068,761,620$ & $1,016,609,640$ & $1,304,372,400$ \\
\hline
\end{tabular}

Source: Langkat Regency Agriculture Office

Table 8: The Value of North Sumatera Food Crop Commodities 2011 - 2015

\begin{tabular}{|l|l|l|l|l|l|}
\hline \multirow{2}{*}{ Commodity } & \multicolumn{5}{|c|}{ Year } \\
\cline { 2 - 6 } & \multicolumn{1}{|c|}{2011} & \multicolumn{1}{|c|}{2012} & \multicolumn{1}{c|}{2013} & \multicolumn{1}{c|}{2014} & \multicolumn{1}{c|}{2015} \\
\hline Rice & $2,955,105,500$ & $3,559,224,500$ & $2,878,653,000$ & $2,977,320,000$ & $3,618,655,500$ \\
\hline Corn & $2,991,945,400$ & $3,350,886,000$ & $2,688,608,700$ & $2,695,730,500$ & $2,755,354,750$ \\
\hline Cassava & $205,650,600$ & $3,740,748,000$ & $3,818,455,500$ & $3,526,455,530$ & $6,359,104,010$ \\
\hline Sweet & $45,822,252,40$ & $57,433,618,00$ & $50,833,937,40$ & $40,468,108,70$ & $22,946,748,50$ \\
potato & 0 & 0 & 0 & 0 & 0 \\
\hline Peanuts & $737,304,200$ & $1,045,000$ & $180,825,185$ & $61,202,370$ & - \\
\hline Soybeans & $28,140,000$ & $233,063,000$ & $28,583,000$ & $356,193,000$ & $342,998,000$ \\
\hline Green beans & $11,201,500$ & $19,279,034$ & $17,305,000$ & $16,331,026$ & $12,175,000$ \\
\hline \multirow{2}{*}{ Total } & $52,751,599,60$ & $68,337,863,53$ & $60,446,367,78$ & $50,101,341,12$ & $36,035,035,76$ \\
& 0 & 4 & 5 & 6 & 0 \\
\hline
\end{tabular}

Source: Agriculture Office of North Sumatera Province (Data processed)

The two tables above are tables of the value of food crop commodity sales in Langkat and North Sumatera Regencies, so the following is the RCA calculation results for Food Crop Commodities in Langkat Regency.

Table 9: RCA Calculation Results

\begin{tabular}{|l|l|l|l|l|l|l|l|}
\hline \multirow{2}{*}{ Year } & \multicolumn{7}{|c|}{ RCA Calculation Results } \\
\cline { 2 - 8 } & Rice & \multicolumn{1}{|c|}{ Corn } & Cassava & $\begin{array}{l}\text { Sweet } \\
\text { potato }\end{array}$ & Peanuts & Soybeans & $\begin{array}{c}\text { Green } \\
\text { beans }\end{array}$ \\
\hline 2011 & 2.62 & 2.01 & 0.95 & 0.84 & 0.32 & 2.30 & 2.60 \\
\hline 2012 & 2.63 & 2.06 & 0.86 & 0.84 & 0 & 3.07 & 3.07 \\
\hline 2013 & 2.10 & 1.11 & 0.87 & 0.90 & 0.54 & 2.84 & 2.84 \\
\hline 2014 & 1.01 & 1.02 & 0.94 & 1.00 & 1 & 1.01 & 2.85 \\
\hline 2015 & 2.27 & 3.25 & 0.44 & 0.67 & 0 & 2.07 & 3.07 \\
\hline Average & 2.13 & 1.89 & 0.81 & 0.85 & 0.37 & 2.26 & 2.89 \\
\hline
\end{tabular}

Source: Processed Data

By looking at the results of the RCA calculation above, it can be concluded that the food plant commodities that have scientific power are rice, corn, soybeans, and green beans. This happens because the production of these food crop commodities is very abundant. Langkat is the fourth largest rice producing district in North Sumatera, which is able to meet local needs and even send it out of the region. In 2011 the RCA results for rice reached 2.62, which means that rice has high competitiveness, the results of this RCA calculation continued to increase in 2012 to 2.63 and 2013 to decrease to 2.10. Even though in the following year the RCA calculation decreased, the RCA calculation results 
still showed a number above 1, namely in 2014 of 1.01 and in 2015 it increased again to 2.27 which means that rice has high competitiveness.

Next is to look at the RCA index which is used to see whether or not there is an increase in the competitiveness of the food crop subsector in Langkat district. The following table is the RCA index

Table 10: RCA Index

\begin{tabular}{|l|l|l|l|l|l|l|l|}
\hline $\begin{array}{c}\text { RCA } \\
\text { Index }\end{array}$ & Rice & Corn & Cassava & Sweet potato & \multicolumn{1}{|c|}{ Peanuts } & Soybeans & Green beans \\
\hline 2015 & 2.25 & 3.19 & 0.47 & 0.67 & 0.00 & 2.05 & 1.08 \\
\hline 2014 & 0.48 & 0.92 & 1.08 & 1.06 & 1.85 & 0.36 & 1.00 \\
\hline 2013 & 0.80 & 0.54 & 1.01 & 1.12 & $\sim$ & 0.93 & 0.93 \\
\hline 2012 & 1.00 & 1.02 & 0.91 & 1.00 & 0.00 & 1.33 & 1.18 \\
\hline 2011 & 0.74 & 0.53 & 0.97 & 1.20 & 2.91 & 1.22 & 1.04 \\
\hline
\end{tabular}

Source: Processed Data

Looking at the RCA Index above, we can see that in 2011 the RCA Index for rice was 0.74, meaning that there was a decrease in the RCA value in 2010 to 2011. In 2012 there was no increase in the competitiveness of rice in Langkat district. In 2013 there was a decrease in the competitiveness of rice, namely by 0.80 and 0.48 in 2014 . In the following year there was an increase in the competitiveness of rice by 2.25 .

\section{$\mathrm{MCl}$ Analysis}

By looking at the data on the distribution of food plant commodity sales in Langkat district, the following is the result of $\mathrm{MCl}$ calculations for the food crop commodity:

Table 11: Calculation Results of $\mathrm{MCl}$ for Food Crops in Langkat Regency

\begin{tabular}{|c|c|c|c|c|c|c|c|c|c|c|c|c|c|c|c|}
\hline \multirow[b]{2}{*}{ Year } & \multicolumn{5}{|l|}{ Rice } & \multicolumn{5}{|c|}{ Sweet potato } & \multicolumn{5}{|c|}{ Green beans } \\
\hline & M & B & A & $\begin{array}{l}\text { Tot } \\
\text { al }\end{array}$ & $\begin{array}{l}\mathrm{MCl} \\
\text { Res } \\
\text { ult }\end{array}$ & M & B & A & $\begin{array}{l}\text { Tot } \\
\text { al }\end{array}$ & $\begin{array}{l}\mathrm{MCl} \\
\text { Res } \\
\text { ult }\end{array}$ & M & B & A & $\begin{array}{l}\text { Tota } \\
\text { I }\end{array}$ & $\begin{array}{l}\mathrm{MCl} \\
\text { Resu } \\
\text { It }\end{array}$ \\
\hline $\begin{array}{l}201 \\
1\end{array}$ & $\begin{array}{l}0.0 \\
26\end{array}$ & $\begin{array}{l}0.7 \\
1\end{array}$ & - & $\begin{array}{l}0.7 \\
3\end{array}$ & 0.86 & $\begin{array}{l}0.6 \\
56\end{array}$ & $\begin{array}{l}0.0 \\
36\end{array}$ & - & $\begin{array}{l}0.6 \\
91 \\
\end{array}$ & 0.83 & - & - & 1 & 1 & 1 \\
\hline $\begin{array}{l}201 \\
2\end{array}$ & $\begin{array}{l}0.3 \\
96\end{array}$ & $\begin{array}{l}0.1 \\
4\end{array}$ & - & $\begin{array}{l}0.5 \\
3\end{array}$ & 0.73 & $\begin{array}{l}0.4 \\
07\end{array}$ & $\begin{array}{l}0.0 \\
93\end{array}$ & $\begin{array}{l}0.0 \\
03\end{array}$ & $\begin{array}{l}0.5 \\
03\end{array}$ & 0.71 & - & - & 1 & 1 & 1 \\
\hline $\begin{array}{l}201 \\
3\end{array}$ & $\begin{array}{l}0.0 \\
25\end{array}$ & $\begin{array}{l}0.7 \\
1\end{array}$ & - & $\begin{array}{l}0.7 \\
3\end{array}$ & 0.86 & $\begin{array}{l}0.4 \\
7\end{array}$ & $\begin{array}{l}0.0 \\
92\end{array}$ & 0 & $\begin{array}{l}0.5 \\
63\end{array}$ & 0.75 & - & - & 1 & 1 & 1 \\
\hline $\begin{array}{l}201 \\
4\end{array}$ & $\begin{array}{l}0.0 \\
02\end{array}$ & $\begin{array}{l}0.9 \\
2\end{array}$ & - & $\begin{array}{l}0.9 \\
2\end{array}$ & 0.96 & $\begin{array}{l}0.3 \\
71\end{array}$ & $\begin{array}{l}0.1 \\
28\end{array}$ & $\begin{array}{l}0.0 \\
01\end{array}$ & 0.5 & 0.71 & - & - & 1 & 1 & 1 \\
\hline $\begin{array}{l}201 \\
5 \\
\end{array}$ & $\begin{array}{l}0.1 \\
62 \\
\end{array}$ & $\begin{array}{l}0.1 \\
4 \\
\end{array}$ & $\begin{array}{l}0.04 \\
9 \\
\end{array}$ & $\begin{array}{l}0.3 \\
5 \\
\end{array}$ & 0.59 & $\begin{array}{l}0.1 \\
97 \\
\end{array}$ & $\begin{array}{l}0.1 \\
35 \\
\end{array}$ & $\begin{array}{l}0.0 \\
36 \\
\end{array}$ & $\begin{array}{l}0.3 \\
68 \\
\end{array}$ & 0.61 & $\begin{array}{l}0 . \\
7 \\
\end{array}$ & $\begin{array}{l}0.0 \\
2 \\
\end{array}$ & $\begin{array}{l}0.00 \\
01\end{array}$ & 0.74 & 0.86 \\
\hline \multirow[b]{2}{*}{$\begin{array}{l}\text { Tah } \\
\text { un }\end{array}$} & \multicolumn{5}{|c|}{ Corn } & \multicolumn{5}{|c|}{ Peanuts } & & & & & \\
\hline & $\mathrm{M}$ & $\mathrm{B}$ & A & $\begin{array}{l}\text { Tot } \\
\text { al }\end{array}$ & $\begin{array}{l}\mathrm{MCl} \\
\text { Res } \\
\text { ult }\end{array}$ & M & B & A & $\begin{array}{l}\text { Tot } \\
\text { al }\end{array}$ & $\begin{array}{l}\mathrm{MCl} \\
\text { Res } \\
\text { ult }\end{array}$ & & \multicolumn{4}{|c|}{$\begin{array}{l}\text { Average } \mathrm{MCl} \\
\text { Results }\end{array}$} \\
\hline $\begin{array}{l}201 \\
1\end{array}$ & $\begin{array}{l}0.0 \\
4\end{array}$ & $\begin{array}{l}0.6 \\
1\end{array}$ & 0 & $\begin{array}{l}0.6 \\
5\end{array}$ & 0.81 & $\begin{array}{l}0.0 \\
4\end{array}$ & - & $\begin{array}{l}0.6 \\
4\end{array}$ & $\begin{array}{l}0.6 \\
8\end{array}$ & 0.82 & & \multicolumn{4}{|c|}{ Food Crops Subsector } \\
\hline $\begin{array}{l}201 \\
2\end{array}$ & $\begin{array}{l}0.0 \\
52\end{array}$ & 0.6 & - & $\begin{array}{l}0.6 \\
5\end{array}$ & 0.8 & - & - & - & - & - & & Con & \begin{tabular}{l|l} 
nodity &
\end{tabular} & $\begin{array}{l}\text { Rata } \\
\mathrm{MCl}\end{array}$ & Rata \\
\hline
\end{tabular}




\begin{tabular}{|c|c|c|c|c|c|c|c|c|c|c|}
\hline $\begin{array}{l}201 \\
3\end{array}$ & $\begin{array}{l}0.0 \\
53\end{array}$ & $\begin{array}{l}0.4 \\
4\end{array}$ & $\begin{array}{l}0.01 \\
1\end{array}$ & $\begin{array}{l}0.5 \\
1\end{array}$ & 0.71 & $\begin{array}{l}0.0 \\
1 \\
\end{array}$ & $\begin{array}{l}0.0 \\
9\end{array}$ & $\begin{array}{l}0.3 \\
6\end{array}$ & $\begin{array}{l}0.4 \\
6\end{array}$ & 0.68 \\
\hline $\begin{array}{l}201 \\
4 \\
\end{array}$ & $\begin{array}{l}0.1 \\
22 \\
\end{array}$ & $\begin{array}{l}0.2 \\
7 \\
\end{array}$ & $\begin{array}{l}0.01 \\
7 \\
\end{array}$ & $\begin{array}{l}0.4 \\
1 \\
\end{array}$ & 0.64 & $\begin{array}{l}0.1 \\
1 \\
\end{array}$ & - & $\begin{array}{l}0.4 \\
4\end{array}$ & $\begin{array}{l}0.5 \\
6\end{array}$ & 0.75 \\
\hline $\begin{array}{l}201 \\
5 \\
\end{array}$ & $\begin{array}{l}0.1 \\
1 \\
\end{array}$ & $\begin{array}{l}0.2 \\
6 \\
\end{array}$ & $\begin{array}{l}0.02 \\
5 \\
\end{array}$ & $\begin{array}{l}0.3 \\
9 \\
\end{array}$ & 0.63 & - & - & - & - & - \\
\hline & \multicolumn{5}{|c|}{ cassava } & \multicolumn{5}{|c|}{ Soybeans } \\
\hline $\begin{array}{l}\text { Tah } \\
\text { un }\end{array}$ & M & B & A & $\begin{array}{l}\text { Tot } \\
\text { al }\end{array}$ & $\begin{array}{l}\mathrm{MCl} \\
\text { Res } \\
\text { ult }\end{array}$ & M & B & A & $\begin{array}{l}\text { Tot } \\
\text { al }\end{array}$ & $\begin{array}{l}\mathrm{MCl} \\
\text { Res } \\
\text { ult }\end{array}$ \\
\hline $\begin{array}{l}201 \\
1\end{array}$ & $\begin{array}{l}0.8 \\
94\end{array}$ & 0 & - & 0.9 & 0.95 & 1 & - & - & 1 & 1 \\
\hline $\begin{array}{l}201 \\
2\end{array}$ & $\begin{array}{l}0.8 \\
27\end{array}$ & $\begin{array}{l}0.0 \\
1\end{array}$ & $\begin{array}{l}1 \mathrm{E}- \\
04\end{array}$ & $\begin{array}{l}0.8 \\
3\end{array}$ & 0.91 & $\begin{array}{l}0.0 \\
38\end{array}$ & $\begin{array}{l}0.0 \\
77\end{array}$ & $\begin{array}{l}0.2 \\
79\end{array}$ & $\begin{array}{l}0.3 \\
94\end{array}$ & 0.63 \\
\hline $\begin{array}{l}201 \\
3 \\
\end{array}$ & $\begin{array}{l}0.7 \\
31 \\
\end{array}$ & $\begin{array}{l}0.0 \\
1 \\
\end{array}$ & $\begin{array}{l}0.00 \\
1 \\
\end{array}$ & $\begin{array}{l}0.7 \\
5 \\
\end{array}$ & 0.86 & - & $\begin{array}{l}0.0 \\
98 \\
\end{array}$ & $\begin{array}{l}0.4 \\
73 \\
\end{array}$ & $\begin{array}{l}0.5 \\
7 \\
\end{array}$ & 0.76 \\
\hline $\begin{array}{l}201 \\
4\end{array}$ & $\begin{array}{l}0.8 \\
61\end{array}$ & 0 & 0 & $\begin{array}{l}0.8 \\
7\end{array}$ & 0.93 & 1 & - & - & 1 & 1 \\
\hline $\begin{array}{l}201 \\
5\end{array}$ & $\begin{array}{l}0.5 \\
21\end{array}$ & $\begin{array}{l}0.0 \\
3\end{array}$ & $\begin{array}{l}0.00 \\
9\end{array}$ & $\begin{array}{l}0.5 \\
6\end{array}$ & 0.75 & $\begin{array}{l}0.1 \\
62\end{array}$ & $\begin{array}{l}0.1 \\
41\end{array}$ & $\begin{array}{l}0.0 \\
49\end{array}$ & $\begin{array}{l}0.3 \\
52\end{array}$ & 0.59 \\
\hline
\end{tabular}

\begin{tabular}{|l|l|}
\hline Rice & 0.8 \\
\hline Corn & 0.718 \\
\hline Cassava & 0.88 \\
\hline $\begin{array}{l}\text { Sweet } \\
\text { potato }\end{array}$ & 0.72 \\
\hline Peanuts & 0.75 \\
\hline Soybeans & 0.79 \\
\hline $\begin{array}{l}\text { Green } \\
\text { beans }\end{array}$ & 0.97 \\
\hline
\end{tabular}

Source: Processed Data

Based on the description above, the average food crop commodity in Langkat Regency is less distributed. This is reflected in the results of $\mathrm{MCl}$ calculations which are almost close to number 1 . The distribution of rice in Langkat district is close to number 1 . In the previous table we can see that the distribution of rice commodity is only spread to two regions and mostly only three regions, namely Medan, Binjai and Aceh. In 2011, the MCI calculation result was 0.69 . The following year the $\mathrm{MCl}$ calculation increased to 0.73 , which means that sales of the rice commodity were less distributed. In the following year the $\mathrm{MCl}$ calculation increased again to 0.86 . The following year, the $\mathrm{MCl}$ calculation decreased again to 0.77 and 0.74 in 2015 . The $\mathrm{MCl}$ results for rice are still far from zero, which means that the distribution of rice sales is still less spread out.

From the three analytical tools above, below will explain again what are the superior and non-superior commodities based on the combination of the three results of the discussion above:

1. Rice is one of the leading food crop commodities that are competitive in Langkat Regency. Rice is said to be superior because the LQ value in 2015 shows that the $L Q$ value is greater than one, namely 1.05 . The RCA calculation result for rice also shows 2.27, meaning that rice has high competitiveness in Langkat Regency because the RCA result is $>1$. Then, by looking at the $\mathrm{MCl}$ result of 0.59 , it means that rice is spread to several areas.

2. Corn is also one of the leading commodities in the food crop sub-sector in Langkat Regency, which is competitive with an LQ result in 2015 of 1.06. Likewise, the RCA with a value of more than one is 3.25 , so that corn is also a competitive food crop commodity. The $\mathrm{MCl}$ results also showed 0.63 , which means that maize is spread over several regions. 
3. By looking at the results of the LQ calculation for cassava in 2015 and in previous years, cassava is not a leading commodity in the food crop sub-sector. In 2015 the LQ calculation for cassava was 0.24 . Similar to the LQ calculation which is below one, the RCA results also show below number 1 , which is 0.44 . This means that cassava is not a competitive food crop commodity in Langkat Regency. The $\mathrm{MCl}$ results also show a value of 0.75 , which means that cassava is spread to several regions.

4. Sweet potato is also not a leading commodity that is competitive in Langkat Regency. In 2015, the LQ value for sweet potatoes did not reach 1, namely 0.07, which means that sweet potato is not a leading commodity in Langkat Regency. The RCA results for sweet potatoes also show a number below 1 , which is 0.67 . With an $\mathrm{MCl}$ calculation of 0.61 .

5. Peanuts in 2015 are also a leading commodity in Langkat Regency. This can be seen from the results of the LQ calculation which is greater than 1 , which is equal to 10.94. However, in previous years the LQ calculation results were less than one. In 2014, the calculation of the RCA for peanuts was 1, meaning that peanuts had competitiveness but were not superior with an $\mathrm{MCl}$ value of 0.75 .

6. Soybean is a leading commodity which is competitive in Langkat Regency. This can be seen from the results of the LQ calculation which is greater than number 1 , namely 2.10 and RCA of 2.07, which means that soybeans have high competitiveness. Soybeans are scattered to several regions with an $\mathrm{MCl}$ calculation of 0.59 .

7. Green beans are also a leading commodity by looking at the results of the LQ calculation which is greater than one, namely 2.35. The results of RCA calculations also show soybeans above 1 , namely 3.07. However, the $\mathrm{MCl}$ results showed 0.86. Mung beans are also scattered in several areas around Langkat.

\section{CONCLUSIONS AND RECOMMENDATIONS}

\section{Conclusion}

The results of data analysis and discussion that have been carried out according to the research objectives, can be concluded as follows:

1. By using the LQ analysis tool, the superior commodities in the food crop subsector are rice, corn, soybeans and green beans. In table 4.2.3 the average LQ value in 2011 to 2015 for rice is 1.04 , corn is 1.08, soybeans are 1.48 and green beans are 1.85 which shows that these commodities are superior because they are greater than 1 . Meanwhile, the non-superior commodities were cassava with a calculation result of 0.34 , sweet potato as much as 0.10 and 0.40 for peanuts which indicated that cassava, sweet potato and peanuts were not superior commodities.

2. By using the RCA and $\mathrm{MCl}$ analysis tools, the commodities of the food crop subsector that are competitive in Langkat Regency are rice, corn, soybeans and green beans. In table 4.2.6. The average value of RCA in 2011 to 2015 for rice was 2.13 , corn was 1.89 , soybeans were 2.26 and green beans were 2.89 which 
indicates that with the RCA analysis, the calculation result is greater than 1 which means commodities has high competitiveness. Commodities that do not have high competitiveness are 0.81 for cassava, 0.85 for sweet potato and peanuts of 0.37 . Furthermore, the average $\mathrm{MCl}$ yield from 2011 to 2015 for rice was 0.80 corn at 0.72 , soybeans at 0.79 and green beans at 0.97 . The $\mathrm{MCl}$ calculation results for cassava were 0.88 , sweet potatoes were 0.72 and peanuts were 0.75

\section{Suggestion}

Based on the results of the discussion and conclusions above, several suggestions can be given, namely:

1. The Langkat Regency government is deemed necessary to make a special regional regulation to protect the diversion of food plants so that the food planting area is maintained and even increases the amount of food crop production, improves agricultural infrastructure, such as building irrigation for food crops, providing incentives to farmers, including guarantees. prices when harvests are large, subsidized seeds and fertilizers

2. The Langkat Regency government is deemed very necessary to maintain food crop price stability during large harvests so that harvest price volatility does not occur

3. It is hoped that further researchers will increase the number of years to be studied and are not only limited to the food crop sub-sector but other subsectors.

\section{REFERENCES}

Agustono. 2013. Analisis Sektor Pertanian Ditinjau Dari Peran Terhadap Pertumbuhan dan Stabilitas Produk Domestik Regional Bruto di Provinsi Jawa Tengah, SEPA : Vol. 9 No.2, Februari 2013, p 283-296

Andayani, Asti. 2010. Analisis Pengembangan Komoditas Unggulan Utama Hortikultura di Kawasan Agropolitan Ciwidey, Kabupaten Bandung, Tesis. Institut Pertanian Bogor : Bogor

Ariefianto, Doddy, Moch. 2012. Ekonometrika Esensi dan Aplikasi Menggunakan Eviews. Penerbit Erlangga : Jakarta

Badan Pusat Statistik Langkat. 2012. Statistik Sektor Perekonomian 2012. Langkat : Sumatera Utara

Dumairy. 1996. Perekonomian Indonesia. Penerbit Erlangga : Jakarta

Enu, Patrick. 2014. Analysis of the Agricultural Sector of Ghana and Its Economic Impact on Economic Growth. Academic Research International Vol. 5, July 2014, p 267277

Hendayana, Rachmat. 2003. Aplikasi Metode Location Quotient (LQ) dalam Penentuan Komoditas Unggulan Nasional. Informatika Pertanian Volume 12, Desember 2003 
Izuchukwu, Okoro-Oji. 2011. Analysis of The Contribution of Agricultural Sector on the Nigerian Economic Development. World Review of Business Research, Vol. 1. No. 1, March 2011, Pp. 191-200

Kurniawan, Rezki, Demmatadju. 2009. Analisis Komoditas Unggulan Regional Sektor Pertanian di Sulawesi Selatan, Tesis. Universitas Hasanuddin : Sulawesi Selatan

Lim, Kang-Taeg. 1997. Analysis of North Korea's Foreign Trade by Revealed Comparative Advantages. Journal of Economic Development, Volume 22, No. 2, December 199, p 97-118

Mayes, Antoni, Maulida, dan Indrawati, Toti. 2009. Analisis Sektor Unggulan dengan Pendekatan Location Quation Kabupaten Pelalawan, (online), (http://www.download.portalgaruda.org/article.php)

Muhammad dan Nuryadin, R. 2009. Identifikasi Potensi Ekonomi Masyarakat Kabupaten Tapin 2009. Bappeda Tapin

Ramli, Anwar. 2015. Strengthening Agricultural Sector Superior Commodities-Based Against the Economic Growth in South Sulawesi Indonesia, International Journal of Advanced Research (2015), Vol.3, Issue 2, P 753-760

Richardson, Harry.W. 2001. Dasar-Dasar Ilmu Ekonomi Regional. Lembaga Penerbit FE UI : Jakarta

Serin, Vildan \& Civan, Abdulkadir. 2008. Revealed Comparative Advantage and Competitiveness: A Case Study for Turkey towards the EU. Journal of Economic and Social Research 10(2), p 25-41

Setyowati, Nuning. 2012. Analisis Peran Sektor Pertanian di Kabupaten Sukoharjo. SEPA: Vol.8 No.2, Februari 2012, p 174-179

Syahza, Almasdi dan Selva, Rina. 2005. Kelapa Sawit : Pengaruhnya Terhadap Ekonomi Regional Daerah Riau. Lembaga Penelitian Universitas Riau.

Syaputra, Riki, Huda, Nurul dan Firdaus. 2015. Peranan Sektor Pertanian Terhadap Perekonomian Kabupaten Agam, E-jurnal Bung Hatta, Vol. 6 No. 3

Tarigan, Robinson. 2005. Ekonomi Regional Teori dan Aplikasi. Penerbit Bumi Aksara: Jakarta

Todaro, Michael P. 2008. Pembangunan Ekonomi. Penerbit Erlangga : Jakarta

Umaru, Aminu dan Zubairu. 2012. An Empirical Analysis of the Contribution of Agriculture and Petroleum Sector to the Growth and Development of the Nigerian Economy from 1960 - 2010. International Journal Social, Science and Education, 2012, Vol.2 Issue 4, $p$ 758-769

Wahyuningsih, Tri, Hehamahua dan Sahupala, A. Kadir. 2014. Determination of Agricultural Sector and Subsector Potentially Leading and with Superior in District Hie Location Quotientmethod Static, Dynamic Input and Ouput Location Quotient. Journal of Economic and Sustainable Development, Vol.5 No.28, 2014, p 72-80

QE Journal | Vol.09 - No.02 - 48 
Wiwin, Suponah. 2008. Analisis Kontribusi Sektoral Terhadap PDRB Kota Malang Menuju Konsep Balance Growth, Tesis. Universitas Widyagama: Malang

Wulandari, Nur Indah. 2008. Penentuan Agribisnis Unggulan Komoditi Pertanian Berdasarkan Nilai Produksi Di Kabupaten Grobogan, Tesis. Universitas Diponegoro : Semarang

Yue, Chang Jun. 2001. Comparative Advantage, Exchange Rate and Exports In China. A Paper Prepared For The International Conference On Chinese Economy "Has China Become A Market Economy". CERDI, Clermont - Ferrand

Yusuf, Muhammad. 2012. Ilmu Ekonomi Regional. Penerbit Perdana Publishing: Medan 